\title{
Evaluation of mucilage and powder of Okra as bio-flocculant in water treatment
}

\author{
Evaluación de mucilage y polvo de Quimbombó \\ como biofloculante en el tratamiento de aguas
}

\section{Avaliação da mucilagem e do pó de Quiabo como bio-floculante no tratamento de águas}

\author{
Livia Carneiro-Marra; Larissa Sad; Marcelo Da Silva-Batista*
}

Chemical Engineering Department, Federal University Of São João Del Rei, Campus Alto Paraopeba, Rodovia Mg 443, Km 5, Pobox 131, Ouro Branco - Mg - Brazil - Cep 36420-000

*marcelobatista@ufsj.edu.br

Fecha recepción: 23 de julio de 2018 Fecha aceptación: 20 de agosto de 2019

\begin{abstract}
Mucilage and powder of okra were evaluated as bio-flocculant in water treatment using jar test. The agitations sets, okra preparation methods and the amount of coagulant/bio-flocculant were evaluated in the turbidity removal. The results showed that agitations set of $150 \mathrm{rpm}$ and then $40 \mathrm{rpm}$ were more effective for reducing turbidity. Turbidity reduction was 39\% using inorganic coagulant $\left(\mathrm{FeSO}_{4}\right)$ alone, but reduction came to $76 \%$ and $88 \%$ by adding okra mucilage and powder, respectively. All results showed that okra powder present better turbidity removal in water treatment. It can be prepared by simple methodology, and also allow the inorganic coagulant reduction in approximately $64 \%$. In okra powder were identified hydroxyl groups that serve as active sites for colloidal particles removal.
\end{abstract}

Keywords: Bio-Flocculant; Okra; Turbidity Removal; Mucilage; Okra Powder; Water Treatment.

\section{Resumen}

El mucílago y el polvo de quimbombó se evaluaron como biofloculante en el tratamiento del agua usando la prueba jar. Los conjuntos de agitación, los métodos de preparación de quimbombó y la cantidad de coagulante / biofloculante se evaluaron en la eliminación de la turbidez. Los resultados mostraron que las agitaciones establecidas de $150 \mathrm{rpm}$ y luego de $40 \mathrm{rpm}$ fueron más efectivas para reducir la turbidez. La reducción de la turbidez fue del $39 \%$ utilizando solo coagulante inorgánico $\left(\mathrm{FeSO}_{4}\right)$, pero la reducción llegó al $76 \%$ y al $88 \%$ al agregar mucílago de quingombó y polvo, respectivamente. Todos los resultados mostraron que el polvo de quimbombó presenta una mejor eliminación de la turbiedad en el tratamiento del agua. Puede prepararse por metodología simple y también permite la reducción del coagulante en aproximadamente $64 \%$. En polvo de quimbombó se identificaron grupos hidroxilo que sirven como sitios activos para la eliminación de partículas coloidales.

Palabras clave: Biofloculante; Quingombó; Eliminación de Turbidez; Mucílago; Polvo de Quimbombó; Tratamiento de Agua.

\section{Resumo}

A mucilagem e o pó de quiabo foram avaliados como biofloculantes no tratamento de água, utilizando o teste jar. Os conjuntos de agitação, os métodos de preparação do quiabo e a quantidade de coagulante/ biofloculante foram avaliados na redução da turbidez. Os resultados mostraram que as agitações de 150 rpm e após 40 rpm foram mais eficazes na redução da turbidez. A redução da turbidez foi de $39 \%$ usando 
somente coagulante inorgânico $\left(\mathrm{FeSO}_{4}\right)$, mas a redução chegou a 76\% e 88\% pela adição de mucilagem e pó de quiabo, respectivamente. Todos os resultados mostraram que o pó de quiabo apresenta uma melhor redução da turbidez no tratamento da água. Ele pode ser preparado por metodologia simples e também permite a redução do coagulante inorgânico em aproximadamente $64 \%$. No pó de quiabo foram identificados grupos hidroxila que servem como locais ativos para a eliminação de partículas coloidais.

Palavras-chave: Bio-Floculante; Quiabo; Remoção de Turbidez; Mucilagem; Pó de Quiabo; Tratamento de Água.

\section{Introduction}

Water collected in rivers and springs contain great diversity of microorganisms, particulate material and dissolved organic matter. The water treatment is performed in water treatment plants (WTP). Among the types of water treatment, coagulationflocculation is the most conventional physicochemical method and widely used to remove water impurities such as suspend or colloidal particles [1]. In the coagulation process occurs the rapid dispersion of chemical coagulants, generally iron or aluminum salts, which causes the destabilization of the colloids and suspended solids by rapid stirring [2]. The flocculation step is necessary when the coagulation does not show total efficient in the formation of agglomerates due low-density particles. Generally, smaller particles will settle more slowly than larger particles of similar density [3].

Recently, there has been interest in natural coagulants for water treatment in developing countries. Natural coagulants are not only water clarifying agents, but they also have antimicrobial and heavy metal removal properties in some instances [4]. The study of the use of natural polymers as flocculation aids has gained more prominence because of the disadvantages of synthetic polymers such as: high cost, possibility of causing environmental damage, and problems related to human health $[5,6]$. On the other hand, natural flocculants or bio-flocculants are non-toxic, biodegradable, stable shear, easily accessible and have low cost [7].

Okra is also known as Abelmoschus esculentus L. (Moench) or Hibiscus esculentus (L.), it is an economically important vegetable crop grown in tropical and subtropical parts of the world [8]. But okra is perishable and about $30 \%$ of Brazilian production is lost and consumers identify the loss of fruit quality by the external yellowing and by the toughening or lack of tissue rupture of the apical pod when twisted with the fingers [9]. However, these discarded fruits are natural flocculants for water treatment and being able to contribute to farmer income [10].
Okra mucilage is a source of natural anionic polysaccharide which is water-soluble and capable of destabilizes colloidal particles and flocculate small particles [11]. The use of okra as bio-flocculant together with coagulant has been used because of its ability to increase the flotation efficiency and decantation of flocs, besides reducing the amount of coagulant [12]. An increased in floc size and shorter period to achieve maximum floc size were observed when extracts of okra was used as coagulant aid, probably due to the high particle attraction capability of the extract, which in real terms could result in lower cost of water treatment [13].

Okra has shown promising results with respect to treatment of industrial textile wastewater [2]. At least $97 \%$ of turbidity removal, $85 \%$ of COD (chemical oxygen demand) reduction and $93 \%$ of colour removal have been reported in these studies. Okra mucilage was effective in low concentrations and comparable to synthetic flocculants in terms of treatment efficiency [14].

In this context, this study evaluated two methods of okra preparation and the amount necessary to use them as bio-flocculant in water treatment.

\section{Material and methods}

\section{Preparation of Okra}

Okra used in this work was bought at local markets in the Southeast of Minas Gerais, in Brazil. For the extraction of mucilage, okra was cleaned, cut into small pieces and excess fiber and seeds were removed. In $12.5 \mathrm{~g}$ of okra was added $500 \mathrm{ml}$ of distilled water and put on shaker at $200 \mathrm{rpm}$ for 2 $\mathrm{h}$ where the mucilage was extracted. The solution was filtered for separation of fibers and viscous mucilage was collected and used as flocculant.

In the preparation powder, okra was cleaned, cut into strips and dried at $140{ }^{\circ} \mathrm{C}$ for $6 \mathrm{~h}$. Okra dry was triturated in a mixer and sieved. Okra powder was selected with particle size less than $0.500 \mathrm{~mm}$ and solution was prepared using $12.5 \mathrm{~g}$ of okra powder and $500 \mathrm{ml}$ of distilled water using shaker at 200 rpm for $30 \mathrm{~min}$. This solution used as flocculant. 


\section{Water used in the experiments}

The water used in the experiments was collected from Ribeirão Arrudas River in São Geraldo neighborhood, Belo Horizonte - MG. This river receives industry wastewater and domestic sewage of 3 cities: Belo Horizonte, Contagem and Sabará. Thus, its water has dark color, unpleasant odor and high turbidity (90.3 NTU).

\section{Experiments in jar-test}

The experiments were conducted in a jar test apparatus with $2 \mathrm{~L}$ of wastewater previously agitated. In the coagulation/flocculation processes were used ferrous sulfate $\left(\mathrm{FeSO}_{4}\right)$ as coagulant, $40 \mathrm{~g} \mathrm{l}^{-1}$ stock solution, and $25 \mathrm{~g}$ $\mathrm{I}^{-1}$ of solution of mucilage extracted or powder of okra as bio-flocculant dissolved in distillated water. The $\mathrm{pH}$ was adjusted to 10 adding $1.2 \mathrm{~g}$ of calcium hydroxide in each jar. This adjustment was necessary since ferrous sulfate $\left(\mathrm{FeSO}_{4}\right)$ has higher coagulant activity in the $\mathrm{pH}$ range 9-11 [15]. Coagulant solution was added at the beginning of the tests.
Experiments were performed with coagulant alone (without okra) and two sets of agitations were tested: $120 \mathrm{rpm}$ for $1 \mathrm{~min}$ (fast mixing) followed by $20 \mathrm{rpm}$ for $15 \mathrm{~min}$ (slow mixing) and $150 \mathrm{rpm}$ for $1 \mathrm{~min}$ followed by $40 \mathrm{rpm}$ for $15 \mathrm{~min}$. After 30 min of stabilization, an aliquot was collected. The agitations set that shown higher turbidity removal was used in the trials with bio-flocculant.

The effect of various bio-flocculant dosages (19-87 $\mathrm{mgl}^{-1}$ ) was evaluation with coagulant concentrations of 40,80 and $110 \mathrm{mg} \mathrm{l}^{-1}$. For each concentrations of ferrous sulfate, experiments were carried out using solutions of mucilage extracted and powder of okra. The okra solution was added at beginning of slow mixing.

\section{Analytical measured}

Turbidity was measured at beginning and stop of each experiment using a turbidimeter (HI 98703 - Hanna instruments). Samples were withdrawn using pipette from $2 \mathrm{~cm}$ depth and analyzed for turbidity. The percentage of turbidity removal was calculated using Equation 1.

$$
\text { Tubidity removal }(\%)=\left(\frac{\text { Turbidity (initial) }- \text { Tubidity (finale) }}{\text { Tubidity (initial) }}\right) \times 100
$$

An FTIR spectrum of okra powder was obtained using an infrared spectrometer (IR Prestige-21) in the region between $4000-400 \mathrm{~cm}^{-1}$ with $4 \mathrm{~cm}^{-1}$ resolution. Okra was pulverized before pressing into potassium bromide pellets.

\section{Results and discussion}

Figure 1 show turbidity removal with ferrous sulfate alone (without okra) in two sets of agitations. In both agitations sets, it is observed that increasing coagulant concentration results in higher percentages of turbidity removal. However, turbidity removal was more efficient with the agitations set $150-40 \mathrm{rpm}$. At low coagulant concentrations more intense agitation (150 rpm) is required to cause more efficient spread of coagulant which will get closer to a greater number of impurities and, consequently, form more clots that will turn into flakes and increase turbidity removal. But reaching the concentration of $140 \mathrm{mg} \mathrm{l}^{-1}$ of coagulant the mixing sets resulted in similar turbidity reductions around $70 \%$. This fact occurs due to the high concentration of coagulant in wastewater.

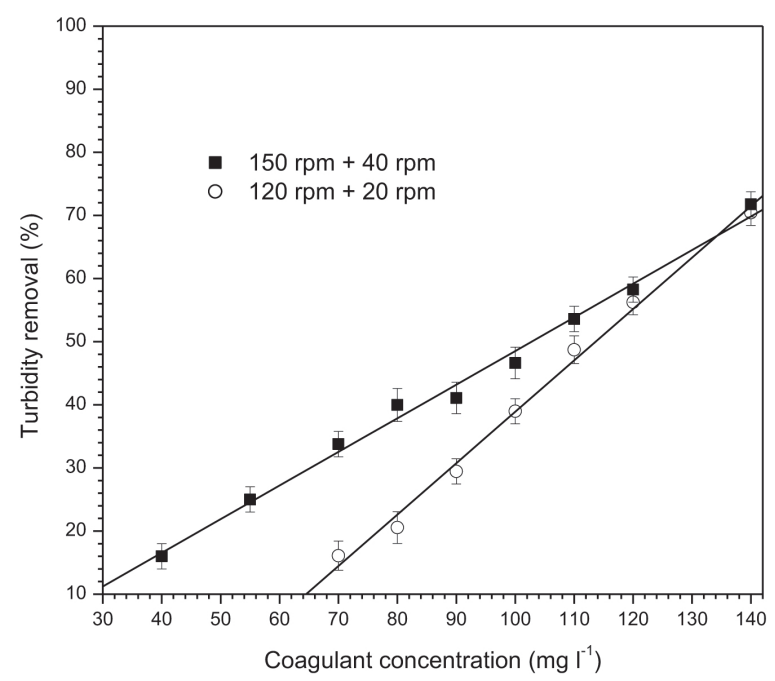

Figure 1. Effect of agitation at turbidity reduction in different coagulant concentrations.

Figure 2 shows the effect of bio-flocculant concentration using mucilage extracted and powder of okra, on turbidity removal using a fixed dosage of ferrous sulfate of $110 \mathrm{mg} \mathrm{l}^{-1}$, constant $\mathrm{pH}$ of 10 and agitations set $150-40 \mathrm{rpm}$. Note that 
turbidity removal using okra was greater than $80 \%$ while that ferrous sulfate alone removed $54 \%$ (for same coagulant dosage and agitation set, Figure 1). This proves that adding okra in water treatment significantly increases the turbidity removal efficiency. Note that the turbidity reduction increased gradually with the increase of bio-flocculant concentration in water until the close values were obtained. Low bio-flocculant dosage $\left(<10 \mathrm{mg} \mathrm{L}^{-1}\right)$ may not have sufficient charges for effective turbidity removal. On the other hand, high bio-flocculant dosage $(>100$ $\mathrm{mg} \mathrm{L}^{-1}$ ), restabilization may occur due to particulate charge reversal [2]. However, okra powder showed greater turbidity reduction than mucilage extracted, mainly at low okra concentrations. Okra powder has fibers together with mucilage and its small particles disperses can contribution for aggregation of molecules in water treatment and, consequently, higher effective turbidity removal. Furthermore, okra powder preparation is more agile, it allows reducing the number of preparation steps and also costs.

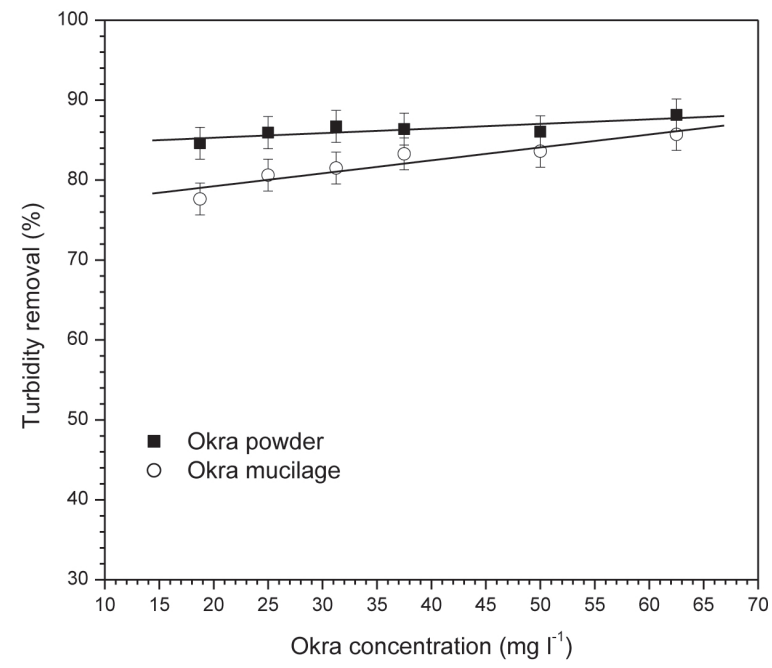

Figure 2. Effect of different concentrations of mucilage extracted and powder okra on turbidity reduction using dosage of ferrous sulfate of $110 \mathrm{mg} \mathrm{l}^{-1}, \mathrm{pH}=10$ and agitations set 150-40 rpm.

Figure 3 shows the effect of bio-flocculant concentration, mucilage extracted and powder of okra, on turbidity removal using a fixed dosage of ferrous sulfate of $80 \mathrm{mg} \mathrm{l}^{-1}$, constant $\mathrm{pH}$ of 10 and agitations set $150-40 \mathrm{rpm}$. Note that okra powder showed greater turbidity reduction than mucilage extracted at different okra concentrations. Turbidity reductions were greater in higher bio-flocculant concentrations being that the greatest turbidity removals were $82 \%$ and $73 \%$ for powder and mucilage extracted of okra, respectively.

Reduction in the dosage of inorganic coagulants is desirable for the environment. Coagulant (ferrous sulfate) reduction of $27 \%\left(110\right.$ to $\left.80 \mathrm{mg} \mathrm{l}^{-1}\right)$ showed small turbidity reduction ( 87 to $82 \%$ ) using $62 \mathrm{mg}$ $\mathrm{I}^{-1}$ of okra powder. This result shows that is possible using low coagulant concentration achieve close turbidity removal. Solid precipitated with low concentration of chemical compound and higher content of organic material is more environmental friendly.

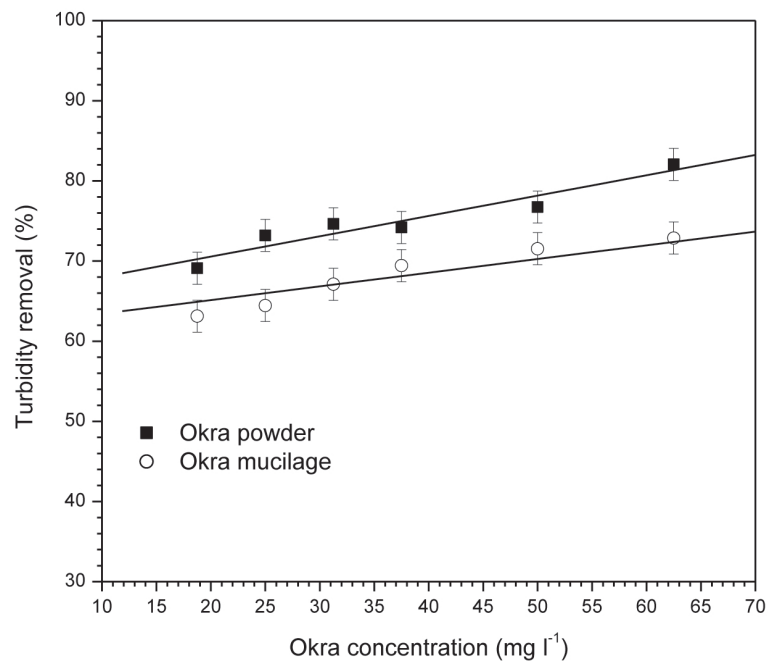

Figure 3. Effect of the concentration of mucilage extracted and powder okra on turbidity reduction using

$80 \mathrm{mg} \mathrm{l}^{-1}, \mathrm{pH}=10$ and agitations set 150-40 rpm.

Figure 4 shows the effect of the bio-flocculant and coagulant concentrations on turbidity removal efficiency. The turbidity removal was less than $60 \%$ at low coagulant concentrations $\left(40 \mathrm{mg} \mathrm{l}^{-1}\right)$ and increased significantly with increasing dosage of okra power. The amount of coagulant and okra powder may not have sufficient charges for particles removal. Note that substantial turbidity reduction occurs when using greater dosage of coagulant and okra powder. It is possible that using high dosage of coagulant (110 $\left.\mathrm{mg} \mathrm{l}^{-1}\right)$ and bio-flocculant have excess of charges for particles removal and, consequently, less pronounced increases of turbidity removal is observed. However, optimum dosage of coagulant should be found near of $80 \mathrm{mg}$ $\mathrm{I}^{-1}$. This value is much close of inorganic coagulant dosage $\left(88 \mathrm{mg} \mathrm{l}^{-1}\right)$ for maximum efficiency of COD removal, turbidity removal and color removal, found in literature [2].

It is noticed that using okra powder $\left(62 \mathrm{mg} \mathrm{l}^{-1}\right)$ allowed coagulant reduction of 110 to $80 \mathrm{mg} \mathrm{l}^{-1}$ keeping the turbidity reduction values higher 
than $80 \%$. Using only $80 \mathrm{mg} \mathrm{l}^{-1}$ of coagulant was obtained only $39 \%$ of turbidity reduction while adding bio-flocculant was up to $88 \%$. Therefore, the combination of coagulant and bio-polymer is able to reduce the amount of chemical agent and increase the turbidity removal in the water treatment process.

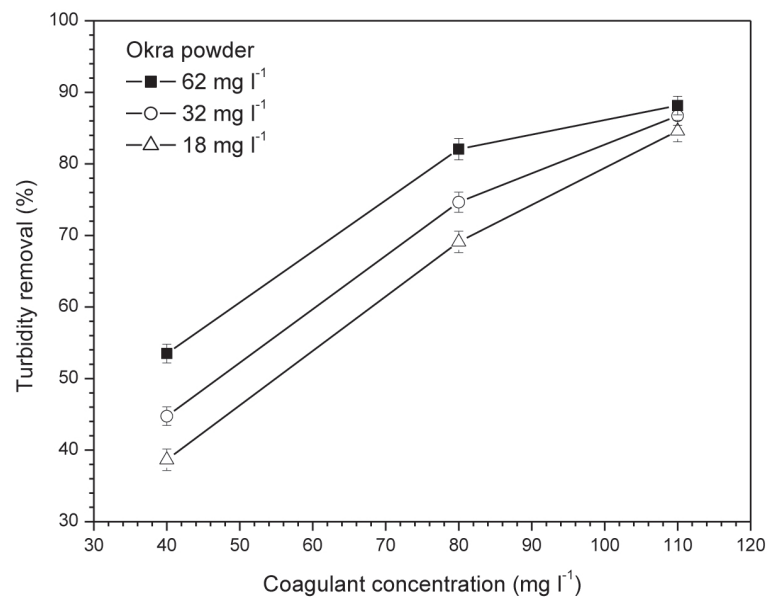

Figure 4. Effect of coagulant concentration on turbidity reduction using 18, 32 and $62 \mathrm{mg} \mathrm{l}^{-1}$ of okra powder, $\mathrm{pH}=10$ and agitations set $150-40 \mathrm{rpm}$.

The use of okra powder favored a greater removal of suspended solids in water treatment. The process of turbidity removal is explained by electrostatic attraction (charge-charge) of okra powder and suspended particles through hydrogen bonds, van der Waals interactions or their combination [16]. Okra powder is composed of organic substances formed by functional groups such as polyphenol and carboxyl that serves as actives sites for particle removal. The identification of functional groups present in okra powder was performed by infrared spectroscopy. Fig. 5 shows FTIR spectrum of okra powder in the resolution range of $4000-400 \mathrm{~cm}^{-1}$.

In Figure 5, the larger band in the region of 3600 $3100 \mathrm{~cm}^{-1}$ with a sharp peak centered at 3271 $\mathrm{cm}^{-1}$ is characteristic $\mathrm{O}-\mathrm{H}$ stretching vibration and hydrogen bond of the hydroxyl groups [17]. These groups serve as active sites for the attachment of colloidal particles and okra powder [2]. Absorption peaks at 2924 and $2853 \mathrm{~cm}^{-1}$ correspond to $\mathrm{C}-\mathrm{H}$ stretching vibration from methyl and methylene group in cellulose and hemicellulose components; while at $1730 \mathrm{~cm}^{-1}$ refers to the carbonyl $\mathrm{C}=\mathrm{O}$ stretching vibration of unconjugated ketone, carboxylic acid and ester in lignin and hemicellulose [18]. The shoulder at $1617 \mathrm{~cm}^{-1}$ may be due to the presence of water in the fibres. A little peak at 1430 $\mathrm{cm}^{-1}$ is associated to the angular deformation on the $\mathrm{OH}$ bonding plane. The two peaks observed at $1370 \mathrm{~cm}^{-1}$ and $1320 \mathrm{~cm}^{-1}$ in the spectrum indicate the bending vibration of $\mathrm{C}-\mathrm{H}$ and $\mathrm{C}-\mathrm{O}$ groups of the aromatic ring in polysaccharides. Furthermore the absorption peaks around 1200-950 $\mathrm{cm}^{-1}$ belong to polysaccharide in cellulose and indicate the presence of $\mathrm{C}-\mathrm{O}$ bonds associated with the presence of functional groups such as alcohol, ether and ester [19].

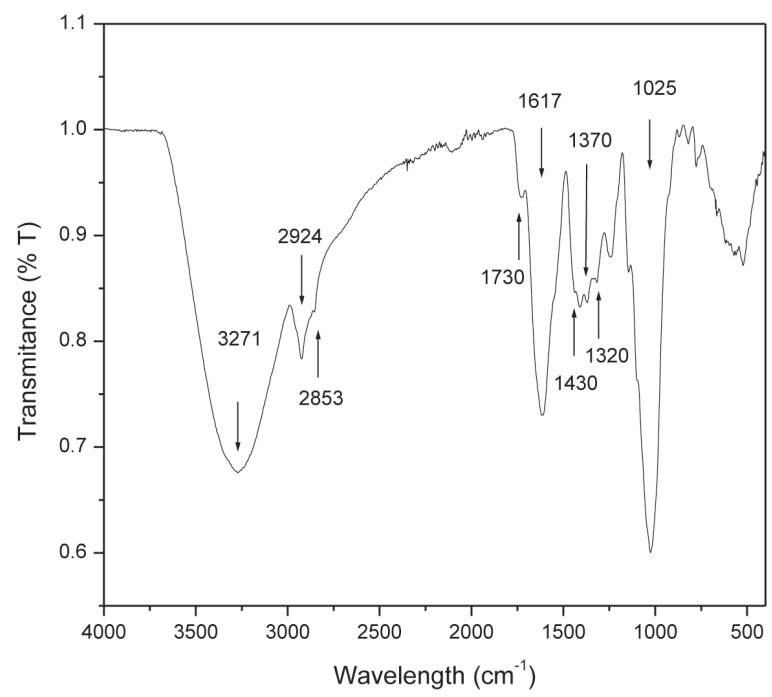

Figure 5. FTIR spectrum of okra powder.

\section{Conclusion}

In water treatment, the turbidity removal was more efficient with the agitations set $150-40 \mathrm{rpm}$ due to best dispersion of the coagulant, especially at low concentrations. The results showed that using $80 \mathrm{mg} \mathrm{l}^{-1}$ of an inorganic coagulant $\left(\mathrm{FeSO}_{4}\right)$ alone was removed only $39 \%$ of turbidity while adding mucilage and powder of okra went up to $76 \%$ and $88 \%$, respectively. These results demonstrate the potential environmental-friendly of bio-polymer present in okra to reduce turbidity and allowed the reduction of $64 \%$ of inorganic coagulant amount in the coagulation-flocculation process. However, the turbidity removal was more efficient when using the okra powder and it increased gradually with the increase of okra concentration in water. In okra powder were identified functional groups that serve as active sites for colloidal particles removal. Furthermore, okra powder can be prepared by simple methodology and it is great interest due to the low-cost, biodegradability and low toxicity. 


\section{Acknowledgement}

The authors thank the Federal University of Minas Gerais for their support in the analysis of infrared spectroscopy.

\section{References}

[1] Lee CS, Robinson J, Chong MF. A review on application of flocculants in wastewater treatment. Process Safety and Environmental Protection Journal. 2014;92:489-508.

[2] Freitas TKFS, Oliveira VM, De Souza MTF, Geraldino HCL, Almeida VC, Fávaro SL, Garcia JC. Optimization of coagulationflocculation process for treatment of industrial textile wastewater using okra ( $A$. esculentus) mucilage as natural coagulant. Industrial Crops and Products Journal. 2015;76:538-44.

[3] Jarvis P, Jefferson B, Gregory JOHN, Parsons SA. A review of floc strength and breakage. Water research. 2005;39:3121-37.

[4] Choy SY, Prasad KMN, Wu TY, Ramanan RN. A review on common vegetables and legumes as promising plant-based natural coagulants in water clarification. International Journal of Environmental Science and Technology. 2015;12:367-90.

[5] Lee CS, Chong MF, Robinson J, Binner E. Optimisation of extraction and sludge dewatering efficiencies of bio-flocculants extracted from Abelmoschus esculentus (Okra). Journal of Environmental Management. 2015;157:320-5.

[6] Anastasakis K, Kalderis D, Diamadopoulos E. Flocculation behavior of mallow and okra mucilage in treating wastewater. Desalination Journal. 2009;249:786-91.

[7] Bolto B, Gregory J. Organic polyelectrolytes in water treatment. Water Research Journal. 2007;41:2301-24.

[8] Kumar DS, Tony DE, Kumar AP, Kumar $K A$, Srinivasa DB, Nadendla R. A review on Abelmoschus esculentus (Okra). Int Res J Pharm App Sci. 2013;3:129-32.

[9] Finger FL, Della-Justina ME, Casali VWD, Puiatti M. Temperature and modified atmosphere affect the quality of okra. Scientia Agricola. 2008;65:360-4.
[10]Kitinoja L, AlHassan HY. Identification of appropriate postharvest technologies for small scale horticultural farmers and marketers in sub-saharan Africa and south Asia - part 1 postharvest losses and quality assessments. Acta Hortic. 2012;934:31-40.

[11] Okolo BI, Menkiti MC, Nnaji PC, Onukwuli OD, Agu CC. The Performance of Okra seed (Hibiscus esculentus L.) Extract in Removal of Suspended Particles from Brewery Effluent by Coag-Flocculation Process. British Journal of Applied Science \& Technology. 2014;34:4791806.

[12]Ding Y, Chen J, Gong W. Synthesis and flocculation characteristics of cationic modified corncob: a novel polymeric flocculant. Agricultural Sciences Journal. 2013;4:23-8.

[13] Jones AN, Bridgeman J. Investigating the characteristic strength of flocs formed from crude and purified Hibiscus extracts in water treatment. Water research. 2016;103:21-9.

[14] Thakur SS, Choubey S. Assessment of coagulation efficiency of Moringa oleifera and Okra for treatment of turbid water. Archives of Applied Science Research. 2014;6:24-30.

[15] Aziz HA, Alias S, Adlan MN, Asaari AH, Zahari MS. Colour removal from landfill leachate by coagulation and flocculation processes. Bioresource technology. 2007;98:218-20.

[16] Jesus E, Cruz PV, Pacífico JA, Silva AS. Removal of turbidity, suspended solids and ions of Fe from aqueous solution using okra powder by coagulation-flocculation process. American journal of water resources. 2013;1:20-4.

[17] Palei NN, Mamidi SK, Rajangam J. Formulation and evaluation of lamivudine sustained release tablet using okra mucilage. J App Pharm Sci. 2016;6:069-75.

[18] Jahan MS, Alam D, Rahman MM, Quaiyyum MA. Isolation and characterization of lignin from okra (Abelmoschus esculentus) fibre and stick. Bangladesh Journal of Scientific and Industrial Research. 2015;50:257-62.

[19]De Rosa IM, Kenny JM, Maniruzzaman M, Moniruzzaman M, Monti M, Puglia D, Santulli C, Sarasini F. Effect of chemical treatments on the mechanical and thermal behaviour of okra (Abelmoschus esculentus) fibres. Composites Science and Technology. 2011;71:246-54. 